Chirurgia (2018) 113: 564-570

No. 4, July - August

Copyright@ Celsius

http://dx.doi.org/10.21614/chirurgia.113.4.564

\title{
Metastatic Breast Cancer to the Cervix Presenting with Abnormal Vaginal Bleeding During Chemotherapy: A Case Report and Literature Review
}

\author{
A Saad Abdalla Al-Zawi, Anita Lazarevska, Mohammed Murwan Omer, Elizabeth Tan, Amira Asaad, \\ Sharlini Sathananthan
}

Basildon \& Thurrock University Hospital, Essex, UK

Corresponding author: Abdalla SAAD ABDALLA M.B.B.Ch, SD in Surgery. PhD, FRCS NHS Consultant Breast Surgeon E-mail: abdalasaad@gmail.com

\section{Rezumat}

Cancer mamar cu metastaze ale colului uterin, cu sângerare vaginală anormală în timpul chimioterapiei: studiu de caz și analiza literaturii

Cele mai întâlnite metastaze ale cancerului mamar invaziv sunt metastazele pulmonare, pancreatice, osoase şi cerebrale. Localizările mai puțin frecvente includ tractul gastrointestinal, pancreasul, spilna, tiroida, glanda suprarenală, rinichii, cordul şi tractul genital feminin. Uterul este o localizare rară pentru metastaze, cu atât mai mult pentru metastaze izolate. Alte localizări ale metastazelor uterine, cu surse extragenitale, includ colonul, stomacul, pancreasul, plămânii, colecistul, melanomul cutanat, vezica urinară şi tiroida. Raritatea cancerului mamar cu metastaze ale colului uterin poate fi explicată prin faptul că acesta din urmă are o mică rezervă de sânge şi un sistem de drenaj limfatic aferent individuale. Diagnosticarea metastazelor colului uterin înainte de descoperirea bolii mamare primare este rară. Metastazele carcinomului lobular invaziv în sistemul genital feminin sunt mai frecvente decât carcinomul ductal invaziv. Această lucrare prezintă un caz cu cancer mamar şi metastaze ale colului uterin.

Cuvinte cheie: adenocarcinom mamar, cancer de col uterin, Citokeratină 7

Abstract

The most common sites of invasive breast cancer metastasis are 
the lungs, liver, bones and brain. Less frequent sites include the gastrointestinal tract, pancreas, spleen, thyroid, adrenals, kidneys, heart and female genital tract. The uterus is reported as a rare site for metastasis, and even more so for an isolated metastasis. Other sites of extra-genital sources for uterine metastases include the colon, stomach, pancreas, gallbladder, lung, cutaneous melanoma, urinary bladder and thyroid. The rarity of breast cancer metastasis to the uterine cervix could be explained by the fact that the cervix has a small blood supply and an afferent lymph drainage system alone. It is rare to diagnose a cervical metastasis prior to eliciting the primary breast disease. Invasive lobular carcinoma metastasises to the female reproductive system more frequently than invasive ductal carcinoma. This paper presents a case of breast cancer metastasis to the cervix.

Key words: breast adenocarcinoma, cervical cancer, Cytokeratin 7

\section{Introduction}

The most frequent sites for breast cancer metastasis are the lungs, bones, liver, and brain (1). However breast adenocarcinoma is the most common extra-genital malignancy that metastasises to the uterus (2).

Extension of the endometrial uterine adenocarcinoma to the cervix is not unusual, but metastases to the cervix from extra-genital sites are rare (3). The reported primary sites are ovarian adenocarcinoma, pancreatic carcinoma (4), primary peritoneal clear cell carcinoma (5), breast, stomach lung and kidney (6). It is important to know the exact nature of the cancer, otherwise it could be mistaken for a

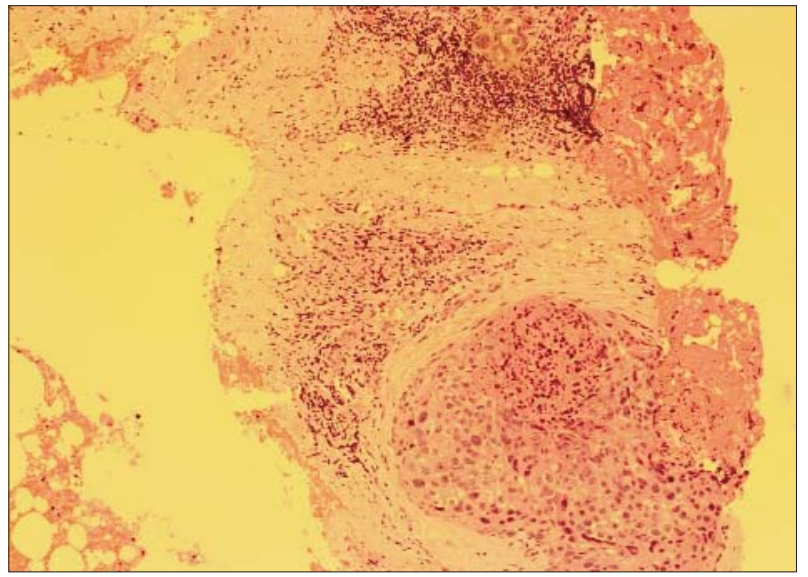

Figure 1. Breast tissue core biopsy infiltrated by Grade 2 invasive ductal carcinoma primary cervical adenocarcinoma. Despite the occurrence of breast cancer metastasis to the uterus being rare, it usually presents as part of widespread metastatic disease (7).

\section{Case Report}

The paper presents a young lady, who has been diagnosed with left breast cancer with metastatic disease in the ipsilateral axilla at the age of 32 years. She has no family history of breast or ovarian cancer. The histology confirmed Grade II invasive ductal carcinoma (Fig. 1), Oestrogen Receptor (ER) negative (Fig. 2), Progesterone Receptor (PR) negative, Her-2 positive and Ki67-70\%. She was treated

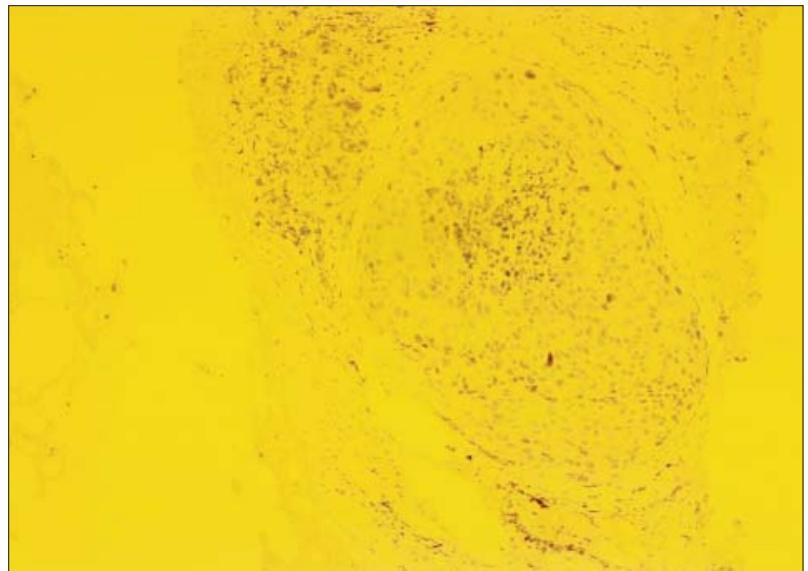

Figure 2. Oestrogen receptor (ER) negative breast invasive ductal carcinoma 
initially with upfront chemotherapy of Adriamycin and Docetaxol, in addition to Trastuzumab. This was followed by a left mastectomy and axillary clearance, in addition to radiotherapy. After finishing the Trastuzumab, she developed skin recurrence in the mastectomy site and chest wall. She received Lapatinib and Capecitabine. The patient had regular gynaecological review all the time, no abnormally detected. Nine months before the cervical metastasis was detected, the patient presented with irregular vaginal bleeding and has Mirena coil in situ. Clinical gynaecological examination including colposcopy which was unremarkable. Cervical smear also was done at the same time, the results showed borderline changes and a repeat screening test in 3 years has been suggested. Trans-vaginal ultrasound, revealed no abnormality other than right ovarian small cyst at that time. In addition, HPV screening was done and found to be negative. The hysteroscopy showed retroverted bulky, mobile uterus and in pipelle biopsy revealed no evidence of infection or malignancy.

Sometime later, she presented with increased irregular vaginal bleeding. CT scan of the

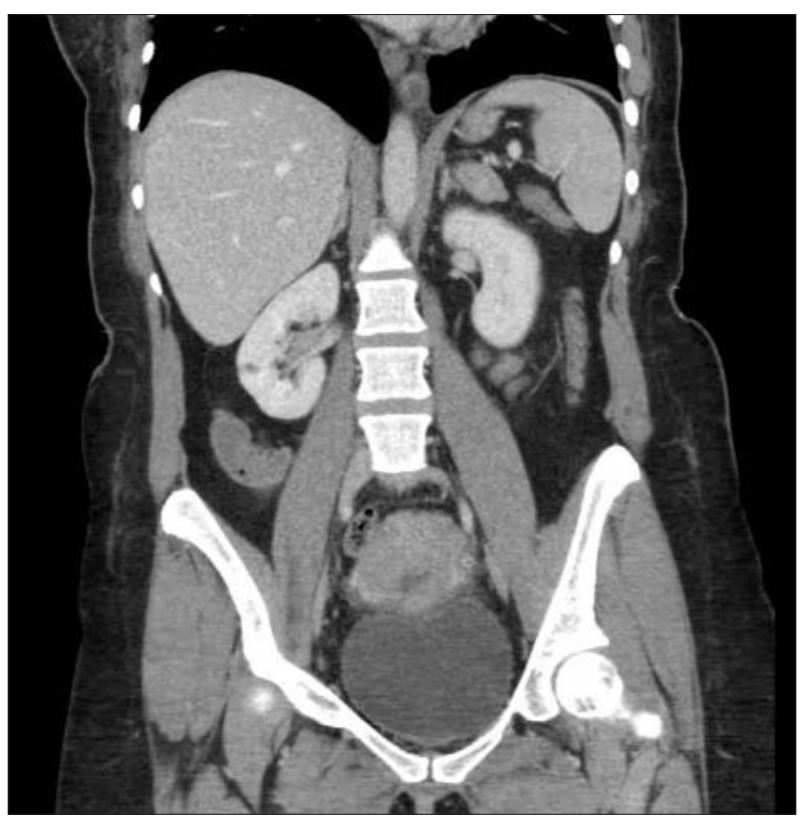

Figure 3. CT abdomen \& pelvis - Coronal view: Prominent cervix with mixed density

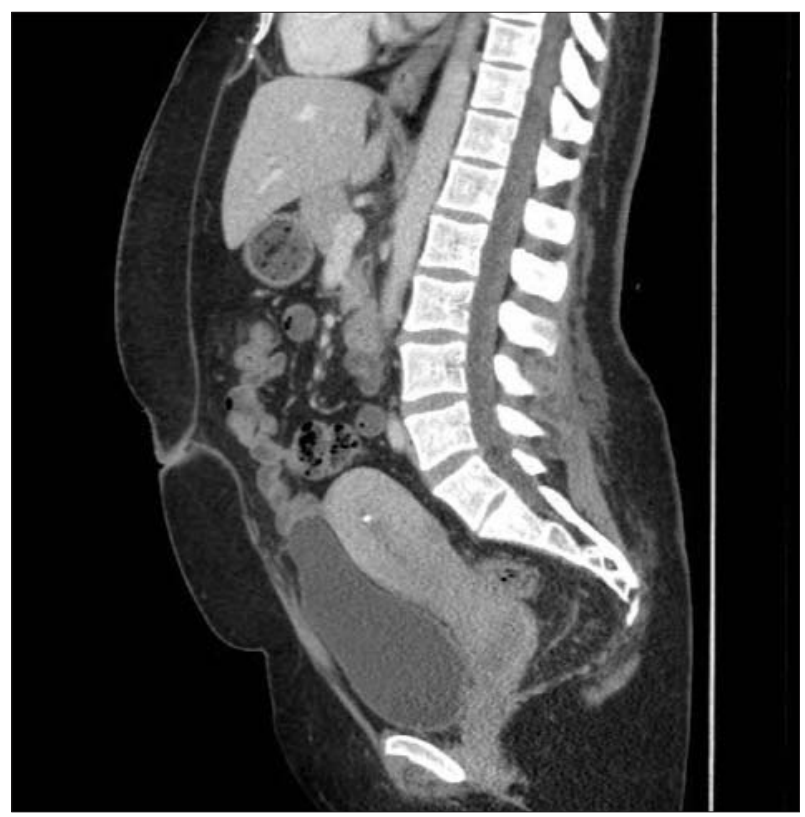

Figure 4. CT abdomen \& pelvis - Sagittal view: Prominent cervix with mixed density

abdomen and pelvis revealed a prominent cervix with mixed density, predominantly hypodense with some partial heterogeneous enhancement (Figs. 3,4, 5).

The hysteroscopy showed a suspicious polyp in the cervix and an endometrial polyp. Biopsy tissue from both areas was composed of extensive high grade malignant tumour cells, forming sheets in areas of a gland-like structure; the features were consistent with adenocarcinoma (Figs. 6, 7).

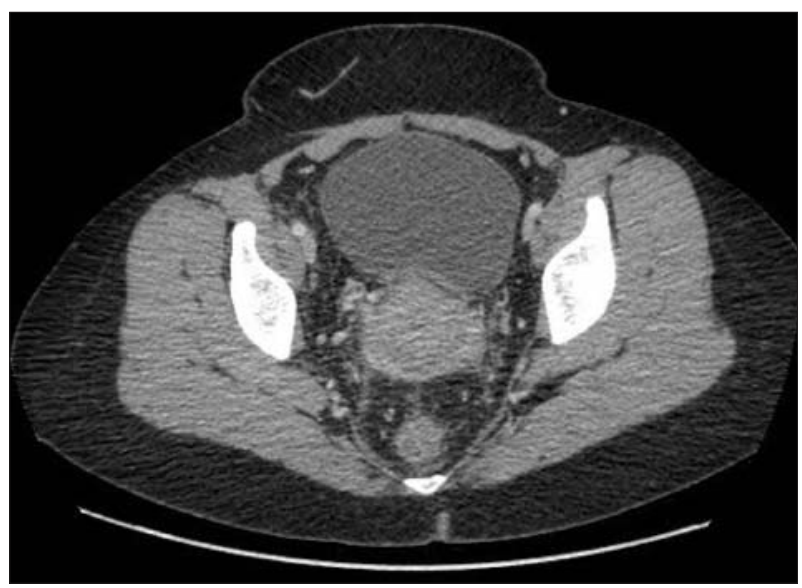

Figure 5. CT pelvis- Axial view: Prominent cervix with mixed density 


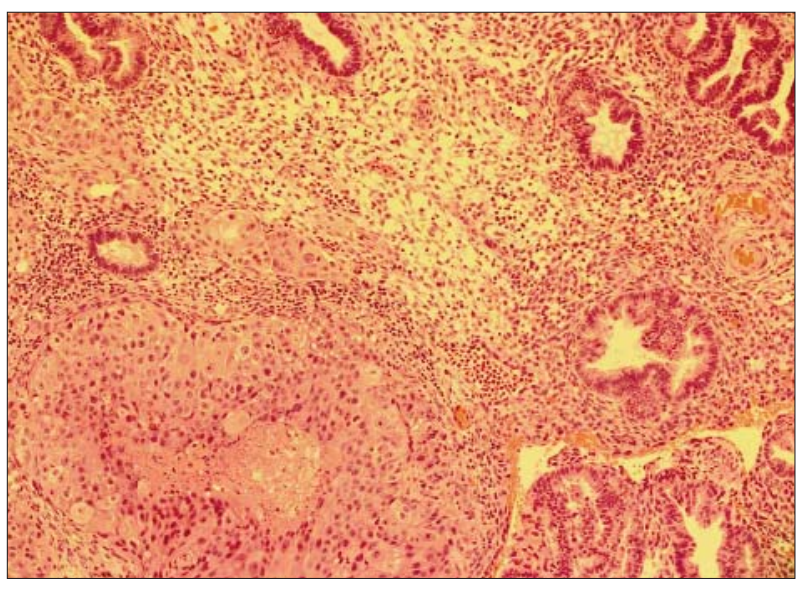

Figure 6. Endometrial biopsy showing metastatic ductal carcinoma

On IHC (Immuno-histochemistry), the tumour cells were positive for CK7, GCDFP15 (Fig. 8) and p53. There was patchy positivity for p16, Vimentin and BCL2, but negativity for CK5, p63, ER (Fig. 9), PR, Napsin A and TTF1. The Ki67 proliferation fraction was $80 \%$. The original breast cancer was reported as ER and PR negative, and Her-2 positive. This makes the metastatic breast IDC the most probable diagnosis.

\section{Discussion}

Breast cancer is considered the most frequently detected worldwide female cancer and the dominant cause of cancer death among women (8).

The usual sites for breast cancer metastasis other than the axillary lymph nodes, are nonaxillary lymph nodes, lungs, pleura, bones, liver, and brain $(9,10,11)$. Less frequent sites are identified as the stomach (12) rectum (13, 14), pancreas (15), spleen, thyroid, adrenals, kidneys, heart, vagina $(16,17)$, uterus and ovaries.

Invasive lobular carcinoma (ILC) is reported as the second most common type of invasive breast cancer after invasive ductal carcinoma (IDC), accounting for $10 \%$ of all breast cancer cases (18).

ILC with a lower grade and positive oestrogen receptors at the time of diagnosis is considered to have a good prognosis $(18,19)$.

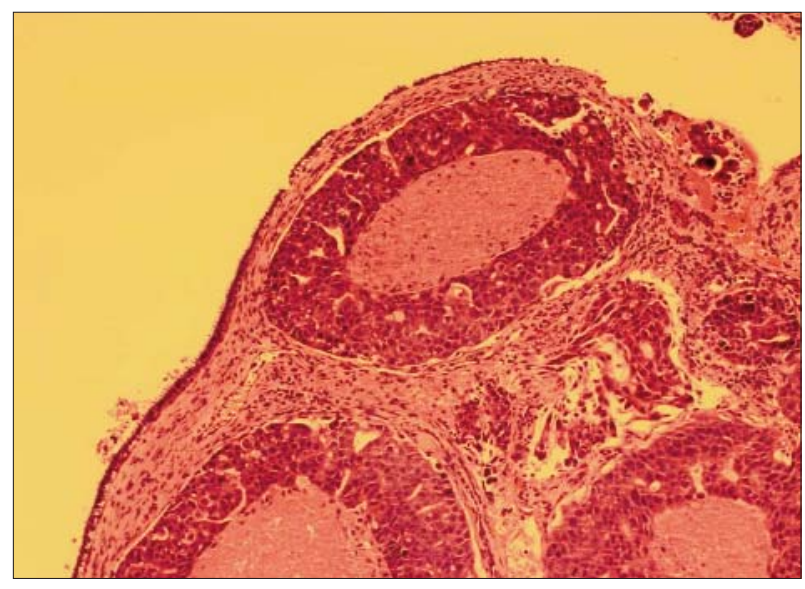

Figure 7. Metastatic deposit in endocervical polyp

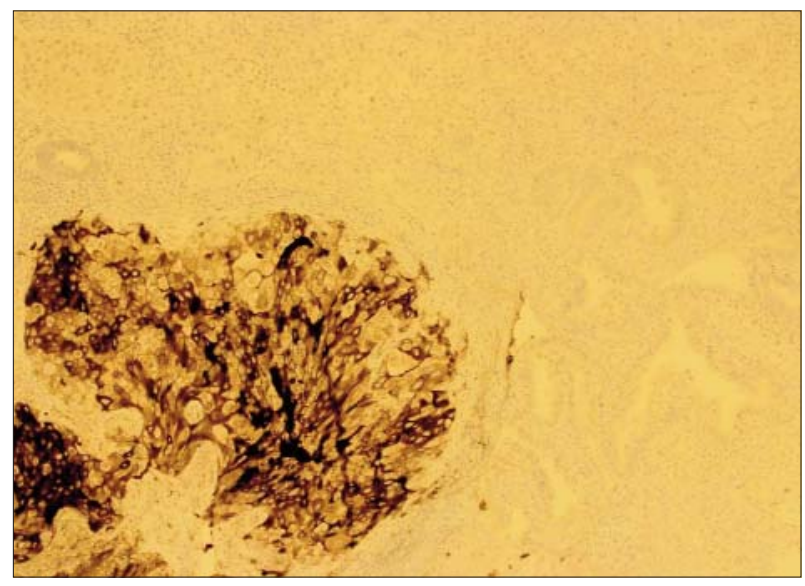

Figure 8. IHC - GCDFP-15 is positive in the metastatic cancer area. This is consistent with a breast primary

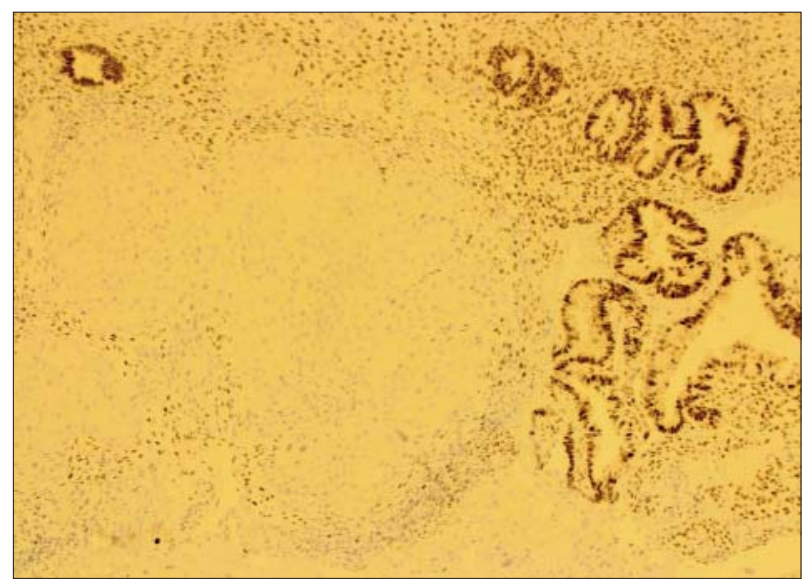

Figure 9. IHC - ER expression is negative in the metastatic cancer. There is positive staining in adjacent normal endometrial glands and stroma 
However ILC metastasises more frequently to the female reproductive system than invasive ductal carcinoma (20). More than $80 \%$ of breast cancers that metastasise to the female genital organs are found to be ILC (21).

Metastatic disease to the female genital organs from an extragenital primary tumour is unusual. A paper published in 1984 by Mazur et al, analysed 325 cases and found that breast and gastrointestinal tract carcinomas are the most frequent extragenital primary tumours (22).

The uterus was reported as a rare site of metastasis, and it is even rarer to be the site of an isolated metastasis (23). Breast adenocarcinoma is the most common extragenital malignancy that metastasises to the uterus (2). The Mazur et al paper from 1984 reported, that in a series of cases of metastatic disease to female genital organs, it was found that $47.3 \%$ of uterine disease came from breast cancer (22).

Other sites of extra-genital sources for uterine metastasis are the colon, stomach, pancreas, gallbladder, lung, cutaneous melanoma, urinary bladder and thyroid (24).

Metastasis to the cervix is rare; it accounts for only $3.7 \%$ of female genital organs metastatic disease (25). The cervix is a less favourable site for metastatic disease from an extra-genital malignancy because of its small size, composition of mainly dense fibromuscular components, restricted blood supply and an afferent lymphatic drainage alone (26).

Age plays an important factor in breast cancer behaviour. Patients of a younger age group are associated with liver and gynaecological metastases (11). A further factor is hormonal sensitivity. It is the hormone sensitive invasive lobular carcinoma subtype which more frequently metastasises to the uterus $(7,27,28)$.

The tumour may present with regional symptoms and signs identical to primary cervical carcinoma. If the uterus is infiltrated, abnormal vaginal bleeding is usually the most frequent presenting symptom. Other symptoms also may present, such as lower abdominal pain and vaginal discharge (2).

Diagnosis of cervical metastasis before the diagnosis of the primary disease is rare; in most cases, the primary breast cancer is diagnosed before the discovery of the metastasis (3).

IHC (Immuno-histochemistry) panel is crucial to differentiate primary from metastatic cervical malignancy. Cytokeratin 7(CK7), is a type II keratin of simple non-keratinizing epithelia. CK7+/CK20+ pattern is seen in endo-cervical cancer (29), and CK7+/CK20pattern is seen in breast cancer (30), endocervical and endometrial carcinoma (31).

Gross cystic disease fluid protein 15 (GCDFP 15) is a glycoprotein originally isolated in human breast gross cystic fluid. It is used as a specific IHC diagnostic marker for tumours originating in the breast $(32,33)$.

Another useful marker is p53, a tumour suppressor gene. It differentiates malignant conditions, which are often $\mathrm{p} 53+$, from reactive and metaplastic conditions, which are usually p53- (34).

The marker p16 is a tumour suppressor protein, which prevents progression into the S-phase of cell cycle. Its overexpression is more frequently seen in high grade endometrial and ovarian carcinoma $(28,35,36)$. In our case it showed patchy positive.

Vimentin is an intermediate filament for mesenchymal tissue, known to be expressed in some epithelial carcinomas. It distinguishes endo-cervical from endometrial adenocarcinoma (37). Its expression is also seen in breast carcinomas (38); it showed uneven positivity in our case.

BCL2 is a regulator protein that regulates cell death (apoptosis); it derives its name from B-cell lymphoma 2. Its gene was detected in chromosomes 14 and 18 in follicular lymphomas. BCL-2 is overexpressed in $\sim 75 \%$ of breast cancer cases; in our case it showed fragmentary expression (39).

The myoepithelial marker p63 rarely stains adenocarcinoma (40); it was negative in our case. Napsin A is a novel aspartic proteinase of the pepsin family, found primarily in lung and kidney (Turner); it was also negative in our case.

Patients with metastatic breast disease who are potentially suitable for curative therapeutic strategy represent only 1-3\% (41). Metastasec- 
tomy in breast cancer is a good option if the metastatic disease is limited to a single operable lesion or to multiple lesions at a single organ site (17).

Other treatment modalities include systemic or regional chemotherapy (taxanes, vinorelbine, capecitabine), hormonal manipulation (third-generation aromatase inhibitors and fulvestrant) and radiofrequency ablation (41). Despite the poor prognosis of this group of patients in general (42), some patients who achieve a complete response remain disease free for prolonged periods, some even beyond 20 years (43).

\section{Conclusion}

This paper highlights the importance of considering a metastatic cancer in the differential diagnosis of abnormal vaginal bleeding, suspicious pelvic examination, or radiological findings in women of perimenopausal ages, with a previous history of breast cancer.

In general, the biologic phenotype of ILC is quite favourable. However patients with ILC do not have a better clinical prognosis than patients with IDC phenotype.

\section{Acknowledgment}

We thank Ms Jessica Eades, from the Radiology Team in the Breast Unit at Basildon \& Thurrock University Hospital, for her valuable support to select the radiographic images.

\section{Conflicts of Interest}

None declared.

\section{Authors' Contributions}

All authors listed on the title page have contributed significantly to the work, have read the manuscript, attest to the validity and legitimacy of the data and its interpretation.

\section{References}

1. Arslan D, Tural D, Tatlı AM, Akar E, Uysal M, Erdoğan G. Isolated uterine metastasis of invasive ductal carcinoma. Case Rep Oncol Med. 2013;2013:793418. doi: 10.1155/2013/793418. Epub 2013 Mar 14.

2. Piura B, Yanai-Inbar I, Rabinovich A, Zalmanov S, Goldstein J. Abnormal uterine bleeding as a presenting sign of metastases to the uterine corpus, cervix and vagina in breast cancer patient on tamoxifen therapy. Eur J Obstet Gynecol Reprod Biol. 1999; 83(1):57-61.

3. Horikawa M, Mori Y, Nagai S, Tanaka S, Saito S, Okamoto T. Metastatic breast cancer to the uterine cervix mimicking a giant cervical leiomyoma. Nagoya J Med Sci. 2012;74(3-4):347-51.

4. McCluggage WG, Hurrell DP, Kennedy K. Metastatic carcinomas in the cervix mimicking primary cervical adenocarcinoma and adenocarcinoma in situ: report of a series of cases. Am J Surg Pathol. 2010;34(5):735-41.

5. Maeda K, Tabata M, Moriyama T, Sakamoto T, Fujimura Y, Ohsawa I, et al. A case of primary peritoneal cancer successfully treated with debulking surgery and postoperative chemotherapy. Gan To Kagaku Ryoho. 2016;43(12):2115-2117. Japanese

6. Song J. Metastatic carcinoma of the uterine cervix from primary breast cancer. JAMA. 1963;184(6):498-500.

7. Huo Z, Gao Y, Zuo W, Zheng G, Kong R. Metastases of basal-like breast invasive ductal carcinoma to the endometrium: a case report and review of the literature. Thorac Cancer. 2015;6(4):548-52.

8. Sharma GN, Dave R, Sanadya J, Sharma P, Sharma KK. Various types and management of breast cancer: an overview. J Adv Pharm Technol Res. 2010;1(2):109-26.

9. Sobinsky JD, Willson TD, Podbielski FJ, Connolly MM. Unusual metastatic patterns of invasive lobular carcinoma of the breast. Case Rep Oncol Med. 2013;2013:986517. Epub 2013 Nov 10. doi:10.1155/2013/986517.

10. Jones GE, Strauss DC, Forshaw MJ, Deere H, Mahedeva U, Mason $\mathrm{RC}$. Breast cancer metastasis to the stomach may mimic primary gastric cancer: report of two cases and review of literature. World J Surg Oncol. 2007 Jul 9;5:75.

11. Cummings MC, Simpson PT, Reid LE, Jayanthan J, Skerman J, Song $S$, et al. Metastatic progression of breast cancer: insights from 50 years of autopsies. J Pathol. 2014;232(1):23-31.

12. Saad Abdalla Al-Zawi A, Lange-Ratajczak M, Chicken W, Karamanakos S, Idaewor P, Elamass M, et al. Pyloric metastases from primary breast cancer - a case report and literature review. JMSCR;05(11):30098-105.

13. Guzmán-Calderón E. Rectal metastases from breast cancer - a case report. J Gastrointest Cancer. 2017:48(2):205-207.

14. Saad Abdalla Al-Zawi A. Rectal metastases from breast invasive lobular carcinoma Oncol Clin Pract 2016;12(5):190-192

15. Bonapasta SA, Gregori M, Lanza R, Sangiorgi E, Menghi A, Scarpini $M$, et al. Metastasis to the pancreas from breast cancer: difficulties in diagnosis and controversies in treatment. Breast Care (Basel). 2010;5(3):170-173.

16. Soares LC, Andrade de Camaret AC. Metastasis of ductal breast carcinoma to the vagina: A Case Report. EMJ Oncol. 2013;1:76-79.

17. Banasiewicz $T$, Krokowicz $Ł$, Biczysko $M$, Janicka-Jedyńska $M$, Pławski A, Paszkowski J, et al. A case of late breast cancer metastases to both suprarenal glands 28 years after mastectomy. Hereditary Cancer in Clinical Practice. 2012;10(Suppl 3):A1.

18. Arpino G, Bardou VJ, Clark GM, Elledge RM. Infiltrating lobular carcinoma of the breast: tumour characteristics and clinical outcome. Breast Cancer Res. 2004;6(3):R149-56.

19. Rakha EA, El-Sayed ME, Powe DG, Green AR, Habashy H, Grainge MJ, et al. Invasive lobular carcinoma of the breast: response to hormonal therapy and outcomes. Eur J Cancer. 2008;44(1):73-83.

20. Toyoshima M, Iwahashi H, Shima T, Hayasaka A, Kudo T, Makino $\mathrm{H}$, et al. Solitary uterine metastasis of invasive lobular carcinoma 
after adjuvant endocrine therapy: a case report J. Med. Case Rep.2015; 9:47.

21. Ustaalioglu BB, Bilici A, Seker M, Salman T, Gumus M, Barisik NO, et al. Metastasis of lobular breast carcinoma to the uterus in a patient under anastrozole therapy. Onkologie.2009;32(7):424-6.

22. Mazur MT, Hsueh S, Gersell DJ. Metastases to the female genita tract. Analysis of 325 cases. Cancer. 1984;53(9):1978-84.

23. Green AE, Biscotti C, Michener C, Belinson J. Isolated cervical metastasis of breast cancer: a case report and review of the literature. Gynecol Oncol. 2004;95(1):267-9.

24. Kumar NB, Hart WR. Metastases to the uterine corpus from extragenital cancers. A clinicopathologic study of 63 cases. Cancer. 1982;50(10):2163-9.

25. Lokadasan R, Ratheesan K, Sukumaran R, Nair SP. Metastatic lobular carcinoma of breast mimics primary cervix carcinoma: Two case reports and a review of the literature. Ecancermedicalscience. 2015;9:571. doi: 10.3332/ecancer.2015.571. eCollection 2015.

26. Bryson CA, de Courcy-Wheeler RH, Wallace RJ. Breast cancer metastasising to the uterine cervix. Ulster Med J. 1999;68(1):30-2

27. Lamovec J, Bracko M. Metastatic pattern of infiltrating lobular carcinoma of the breast: an autopsy study. J Surg Oncol. 1991; 48(1):28-33.

28. Le Bouëdec G, Kaufmann P, De Latour M, Reynaud P, Fonck Y, Dauplat J. Uterine metastases originating from breast cancer. Apropos of 12 cases. Arch Anat Cytol Pathol. 1993;41(3-4):140-4. French

29. Vang R, Gown AM, Barry TS, Wheeler DT, Yemelyanova A, Seidman $\mathrm{JD}$, et al. Cytokeratins 7 and 20 in primary and secondary mucinous tumors of the ovary: analysis of coordinate immunohistochemical expression profiles and staining distribution in 179 cases. Am J Surg Pathol. 2006;30(9):1130-9

30. Tot T. Patterns of distribution of cytokeratins 20 and 7 in special types of invasive breast carcinoma: a study of 123 cases. Ann Diagn Pathol. 1999;3(6):350-6.

31. Castrillon DH, Lee KR, Nucci MR. Distinction between endometrial and endocervical adenocarcinoma: an immunohistochemical study. Int J Gynecol Pathol. 2002;21(1):4-10.

32. Bhargava R, Beriwal S, Dabbs DJ. Mammaglobin vs GCDFP-15: an immunohistologic validation survey for sensitivity and specificity. Am J Clin Pathol. 2007;127(1):103-13.
33. Darb-Esfahani S, von Minckwitz G, Denkert C, Ataseven B, Högel B Mehta K, et al. Gross cystic disease fluid protein 15 (GCDFP-15) expression in breast cancer subtypes. BMC Cancer. 2014;14:546.

34. McKenney JK, Desai S, Cohen C, Amin MB. Discriminatory immunohistochemical staining of urothelial carcinoma in situ and non-neoplastic urothelium: an analysis of cytokeratin 20, p53, and CD44 antigens. Am J Surg Pathol. 2001;25(8):1074-8.

35. Vang R, Shih IM, Kurman RJ. Ovarian low-grade and high-grade serous carcinoma: pathogenesis, clinicopathologic and molecular biologic features, and diagnostic problems. Adv Anat Pathol. 2009;16(5):267-82.

36. Phillips V, Kelly P, McCluggage WG. Increased $p 16$ expression in high-grade serous and undifferentiated carcinoma compared with other morphologic types of ovarian carcinoma. Int J Gynecol Pathol. 2009;28(2):179-86.

37. Kong CS, Beck AH, Longacre TA. A panel of 3 markers including p16, ProExC, or HPV ISH is optimal for distinguishing between primary endometrial and endocervical adenocarcinomas. Am J Surg Pathol. 2010;34(7):915-26.

38. Hemalatha A, Suresh TN, Kumar MLH. Expression of vimentin in breast carcinoma, its correlation with Ki67 and other histopathological parameters. Indian J Cancer. 2013;50(3):189-94.

39. Merino D, Lok SW, Visvader JE, Lindeman GJ. Targeting BCL-2 to enhance vulnerability to therapy in estrogen receptor-positive breast cancer. Oncogene. 2016;35(15):1877-87.

40. Mukhopadhyay S, Katzenstein AL. Subclassification of non-small cell lung carcinomas lacking morphologic differentiation on biopsy specimens: Utility of an immunohistochemical panel containing TTF-1, napsin A, p63, and CK5/6. Am J Surg Pathol. 2011;35(1): 15-25.

41. Pagani O, Senkus E, Wood W, Colleoni M, Cufer T, Kyriakides S, et al. International guidelines for management of metastatic breast cancer: can metastatic breast cancer be cured? J Natl Cancer Inst. 2010;102(7):456-63.

42. Singletary SE, Walsh G, Vauthey JN, Curley S, Sawaya R, Weber KL, et al. A role for curative surgery in the treatment of selected patients with metastatic breast cancer. Oncologist. 2003;8(3):241-51.

43. O'Shaughnessy J. Extending survival with chemotherapy in metastatic breast cancer. Oncologist. 2005;10 Suppl 3:20-9. 